\title{
OLIVINE CHEMISTRY OF EXCEPTIONALLY YOUNG (HOLOCENE) KIMBERLITE OF THE IGWISI HILLS VOLCANO, TANZANIA
}

\author{
${ }^{1}$ Buisman*I., ${ }^{1}$ Sparks R.S.J., ${ }^{2}$ Brown R.J., ${ }^{3}$ Manya S., ${ }^{1}$ Kavanagh J., ${ }^{1}$ Walter M.J. \\ ${ }^{1}$ University of Bristol, Bristol, United Kingdom \\ ${ }^{2}$ Durham University, Durham, United Kingdom \\ ${ }^{3}$ University of Dar es Salaam, Dar es Salaam, Tanzania \\ *Presenting author now at University of Cambridge (email: ib330@cam.ac.uk)
}

\section{INTRODUCTION}

The Igwisi Hills Volcano (IHV) comprises three small, asymmetric, cratered pyroclastic cones and lies along a NESW tending line. It is situated on the western edge of the Tanzanian Archean Craton, Tanzania (Figure 1). The volcano has produced small volume pahoehoe lavas and a coulee. The pyroclastic deposits and lava are the youngest magmatic rocks on the Tanzanian Craton, consisting of the unusual combination of small olivine-dominated uppermantle peridotite xenoliths within a carbonate rich igneous matrix. Xenoliths of basement are found in the lavas and pyroclastic deposits (Dawson 1994 and Brown in press). The IHV contains igneous minerals such as olivine, Crspinel, titanomagnetite, perovskite, monticellite, apatite, phlogopite (including the Ba-rich variety; kinoshitalite) and calcite; a mineral assemblage typical of kimberlites (Mitchell 1986 and Sparks 2009). The IHV is a unique example of extrusive kimberlite volcanism that was first dated by perovskite $\mathrm{U}-\mathrm{Pb}$ giving an imprecise age of $0 \pm 29$ Ma (Batumike 2008). A more precise age of $10.2 \pm 3.0 \mathrm{ka}$ has recently established by cosmogenic ${ }^{3} \mathrm{He}$ dating of olivine crystals from lavas making them the youngest kimberlite volcanoes on Earth (Brown in press). Until recently, work on this volcano had been restricted to samples from the lava flow on the NE flank of the NEvolcano (Dawson 1994 and Reid 1975).

The unaltered Igwisi olivine and the presence of both lava and pyroclastic deposits, gives a unique opportunity to identify different olivine populations and elucidate their origin in two different cooling regimes. From the mineral chemistry and elemental X-ray mapping three types of olivines are recognised. Evidence from petrographic and mineral analysis of the olivine, implies a period of stagnation (eg. a failed dyke) followed by a second pulse that successfully reaches the surface.

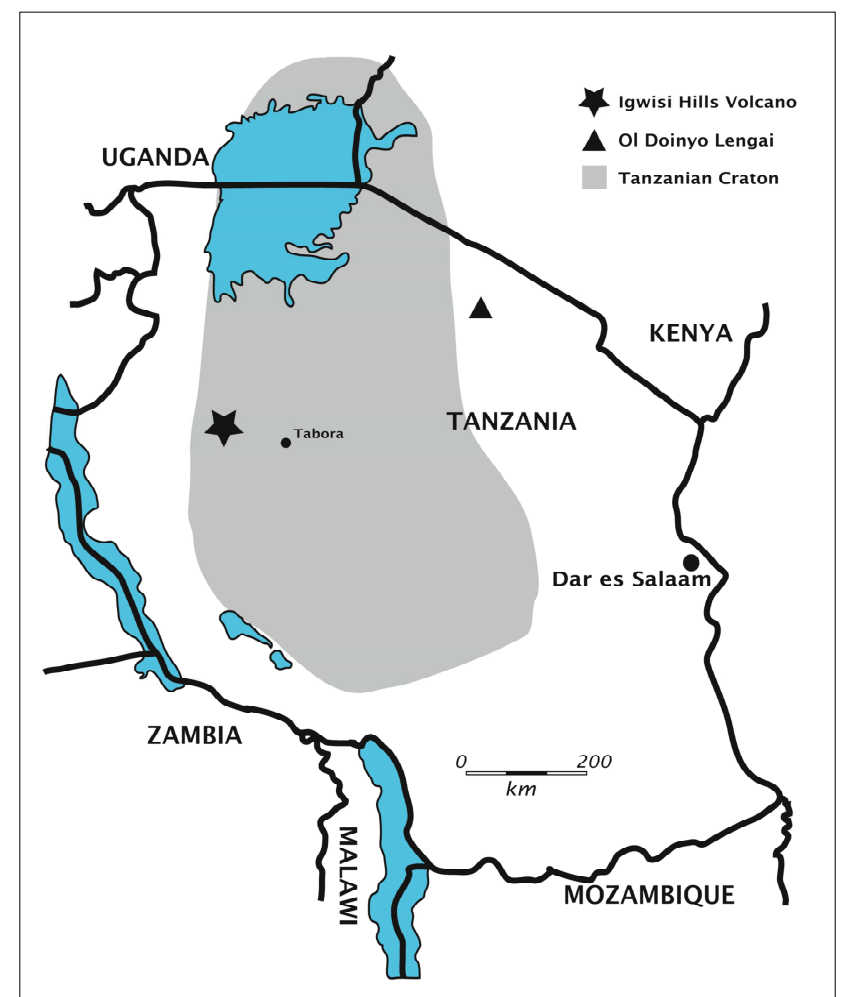

Figure 1: The location of the Igwisi Hills Volcano (IHV, depicted by a star) on the western edge of the Tanzanian Craton.

\section{OLIVINE CHEMISTRY}

Igwisi olivines are either completely fresh or have localised minor serpentinisation. They are forsterite rich with a limited compositional range $\left(\mathrm{Fo}_{88}\right.$ to $\left.\mathrm{Fo}_{92}\right)$ and very $\mathrm{Al}_{2} \mathrm{O}_{3}$ poor $(<0.01 \mathrm{wt} \%)$. We recognise three types of olivines on the basis of crystal shape, crystal size, zoning 


\section{$10^{\text {th }}$ International Kimberlite Conference, Bangalore - 2012}

patterns and associated minerals. One type of olivine (typeIa) corresponds to the micro-xenolith population that consist of large $(10-30 \mathrm{~mm})$, typically polycrystalline aggregates that are ellipsoidal, rounded crystals with a narrow compositional range $\left(\mathrm{Fo}_{89-91}\right)$. They commonly contain inclusions such as garnet, opx and $\mathrm{Cr}$-spinel with some type-Ia grains mantled by zones of perovskite and $\mathrm{Mg}$-Al-spinel. These type-Ia olivines are considered to be micro- xenoliths of mantle origin. A second type-I olivine is recognised (type-Ib), which at smaller $(0.3$ to $10 \mathrm{~mm})$ and contains an unzoned core similar in composition to type-Ia grains. The type-Ib cores are mantled by zoned overgrowth rims. Type-II olivine are smaller $(<300 \mu \mathrm{m})$, unstrained and subhedral grains set in the groundmass. Chemical analysis demonstrates a chemical similarity between type-Ib overgrowth rims and type-II olivines. The final group (typeIII) of olivine are found as inclusions in titanomagnetite host crystals and as polycrystalline intergrowths of titanomagnetite and olivine intergrowths. The chemical composition of type-III olivine falls into two sub-groups for inter-growths and inclusions.

\section{Phosphorous Zoning}

P-zoning has been found to be widespread in olivines from different environments including terrestrial basalts, andesites, dacites, komatiites and martian meteorites (Milman-Barris 2008). P- zoning is produced during rapid growth, when the $\mathrm{P}$ in the melt is in excess of equilibrium partitioning. Therefore, this zoning reflects the crystalgrowth-rate variations within these zoning patterns. In the study by Milman-Barris (2008), a positive correlation was observed between $\mathrm{P}, \mathrm{Cr}$ and $\mathrm{Al}$ suggesting coupled substitution between these elements. The zoning of $\mathrm{P}, \mathrm{Cr}$ and $\mathrm{Al}$, however, was shown to be independent of $\mathrm{Fe} / \mathrm{Mg}$ zoning. The P-zoning is believed to be preserved due to the high charge of the $\mathrm{P}^{5+}$ cation, which would diffuse the slowest compared to di- and tri-valent cations like $\mathrm{Mg}, \mathrm{Fe}$ and $\mathrm{Cr}$.

Igwisi type-Ib and type-II olivines show prevalent $\mathrm{P}$ zoning with a positive correlation between $\mathrm{Cr}$ and $\mathrm{P}$. The $\mathrm{P}$ zoning is limited to the overgrowth rims in type-Ib olivines but is seen in the whole type-II olivine grain. The presence of P-zoning in type-II olivines and type-Ib overgrowth rims demonstrate that the olivine crystallised from the melt as it grew and cooled rapidly during magma ascent and indicates qualitatively higher temperatures prior to eruption.

\section{NiO Zoning}

$\mathrm{NiO}$ exhibits two distinct zoning patterns in type-Ib olivine: normal zoning and "relic-normal-zoning". The latter zoning feature sees an initial decrease in $\mathrm{NiO}$-content from the centre towards the core/rim interface (normal zoning) followed by a rapid increase (reverse zoning) to the maximum $\mathrm{NiO}$ concentration in the profile where the zoning returns to normal zoning resulting in a 'hump' known as 'relic normal zoning' (Kohn 1989). The one type of profile is not restricted to just one sample, but rather an olivine with a normal zoning feature can be found next to another olivine exhibiting the relic-normal-zoning pattern within the same sample.

The 'relic' feature allows for the calculation of the duration of re-equilibration. The poor constraint of kimberlite magma temperatures prompted the use of a range of temperatures $\left(850-1350{ }^{\circ} \mathrm{C}\right)$ for this calculation. The minimum temperature is based on the presence of biotitebearing basement gneiss clasts in the central lava (Brown in press) which should have broken down if heated $>850{ }^{\circ} \mathrm{C}$ (Brown 1970). The higher temperature estimate is chosen from experimental studies on model carbonated lherzolite (Gudfinnsson 2005). Calculated residence times in this temperature interval range from a couple of years (at 1350 $\left.{ }^{\circ} \mathrm{C}\right)$ to centuries $\left(850{ }^{\circ} \mathrm{C}\right)$.

\section{Water Content}

The water content in type-Ia and Ib olivine from both pyroclastic deposits and lava was measured using both SIMS and FTIR methods. Olivine crystals from pyroclastic deposits show relatively homogenous water content of $<35$ ppm and $<80$ ppm by SIMS and FTIR respectively. Olivine xenocrysts in lava show a large water variation, with the water concentration decreasing markedly from the core $(>100 \mathrm{ppm})$ to the rim $(<20 \mathrm{ppm})$. FTIR on type-Ib olivine demonstrates that this change in water concentration is accompanied by a change in $\mathrm{H}$ incorporation mechanism that is linked to the composition change in the olivine.

\section{CONCLUSION}

The study of the olivine chemistry in detail (phosphorous zoning in olivine proposed to crystallise from the melt, water and $\mathrm{NiO}$ profiles in type-Ib olivine) has allowed for a preliminary petrogenetic model to be proposed for IHV.

Water rich kimberlite arrives at mid mantle lithosphere depths $\left(110 \mathrm{~km}\right.$ and $\left.850{ }^{\circ} \mathrm{C}\right)$ where the magma stalls (recorded in $\mathrm{NiO}$ profiles to last from a few years to centuries). Here, the magma disrupts the mantle to mix in xenocrystal olivine which is dry and mixes in these xenocrysts/microxenocrysts thoroughly for a period of time. The olivine absorbs the water from the wet kimberlite allowing for the olivine to reach such high water concentrations. The kimberlite then ascends rapidly (as evidenced by phosphorous zoning) with its wet olivine cargo and progressively degasses during ascent forming the low water rims by diffusion. 


\section{$10^{\text {th }}$ International Kimberlite Conference, Bangalore - 2012}

\section{References}

Batumike, J. M., Griffin, W. L., Belousova, E. A., Pearson, N. J., O'Reilly, S. Y., Shee, S. R. (2008) LAM-ICPMS U-Pb dating of kimberlitic perovskite: Eocene-Oligocene kimberlites from the Kundelungu Plateau, DR Congo. Earth and Planetary Science Letters, v. 267, pp. 609-619.

Brown, R., Manya, S., Buisman, I., Fontana, G., Field, M., Niocaill, C. M., Sparks, R., Stuart, F. (in press) Physical volcanology, geomorphology, and cosmogenic $3 \mathrm{He}$ dating of the youngest kimberlite volcanoes on earth (the Holocene Igwisi Hills Volcanoes, Tanzania). Bulletin of Volcanology.

Brown, G. C and Fyfe, W. S. (1970) The production of granitic melts during ultrametamorphism. Contributions to Mineralogy and Petrology, v. 28, pp. 310-318.

Dawson, J. B. (1994) Quaternary kimberlitic volcanism on the Tanzania craton. Contributions to Mineralogy and Petrology, v. 116, pp. 473485.

Gudfinnsson, G. H and Presnall, D. C. (2005) Continuous gradations among primary carbonatitic, kimberlitic, melilititic, basaltic, picritic, and komatiitic melts in equilibrium with garnet lherzolite at 3-8 GPa. Journal of Petrology, v. 46, pp. 1645-1659.

Kohn, S. C., Henderson, C. M. B., Mason, R. A. (1989) Element zoning trends in olivine phenocrysts from a supposed primary highmagnesian andesite: An electron-and ion-microprobe study. Contributions to Mineralogy and Petrology 103, 242-252.

Milman-Barris, M. S., Beckett, J. R., Baker, M. B., Hofmann, A. E., Morgan, Z., Crowley, M. R., Vielzeuf, D., Stolper, E. (2008) Zoning of phosphorus in igneous olivine. Contributions to Mineralogy and Petrology, v. 155, pp. 739-765.

Mitchell, R. H. (1986) Kimberlites. Mineralogy, Geochemistry and Petrology, 1st Edition. Springer.

Reid, A., Donaldson, C., Dawson, J. B. (1975) The Igwisi Hills extrusive. Physics and Chemistry of the Earth, v. 9, pp. 199-218.

Sparks, R., Brooker, R., Field, M., Kavanagh, J. (2009) The nature of erupting kimberlite melts. Lithos, v. 112, pp. 429-438. 